\title{
GENDER GAP IN AGRICULTURAL PRODUCTIVITY IN NIGERIA: A COMMODITY LEVEL ANALYSIS
}

\author{
Solomon Abayomi Olakojo ${ }^{1}$
}

\begin{abstract}
Summary
This study assesses gender gap in agricultural productivity across selected major crops grown by Nigerian farmers including cassava, yam, maize, guinea corn, bean and millet. The data for the study is sourced from the Living Standards Measurement Study-Integrated Surveys on Agriculture for the year 2012/2013. The pairwise mean comparisons was applied to determine the extent of gender gap in agricultural productivity, inputs access and other variables; while non-parametric quantile regression technique was employed to assess the relationship between input use and gender gaps in farm outputs. The key finding is that gender gaps in farm output is low with quantity harvested and harvest sales of male managed plots marginally higher than female managed plots by $0.22 \%$ and $6.24 \%$, respectively. The gender productivity gaps vary across selected crops and it is more pronounced in cassava, yam and maize production, while it is mild in other crops. The gender farm productivity gaps are traceable to longer farming experience in favour of men and labour market imperfection which is biased against women. Hence, labour market imperfections against women need to be addressed. This requires a formalized farming system which is presently lacking in Nigeria.
\end{abstract}

Key Words: Gender gap, Agricultural productivity, Non-parametric regression technique JEL: J16, J43, Q12, Q15

\section{Introduction}

In the past three decades, there has been increased focus on gender issues and women empowerment in reference to agriculture and economic development. This is based on the increasing recognition that development outcomes can be adversely affected by the failure to pay closer attention to the differentiated societal positions of men and women - in terms of resource allocation, opportunities and rights- in the formulation, design and implementation of development policies and projects (Dejene, 2007). The World Bank and the United Nations warn that the "failure to recognize the [gender] roles, differences and inequities pose a serious threat to the effectiveness of the agricultural development agenda" (World Bank, FAO, IFAD, 2009). African Development Bank (2015) also acknowledges that the increased integration

1 Solomon Abayomi Olakojo, Lecturer, University of Ibadan, Faculty of Economics, Department of Economic, Ibadan, Nigeria. Email: solomonolakojo@gmail.com 
of Africa's agricultural sector into the global value chain is critical for transformation in the region; however, "a central element of this transformation is the economic empowerment of women through improved productivity and increased participation in commercial and higher value-add activities in agriculture" (AfDB, 2015).

In sub-Saharan Africa (SSA), agriculture is critical for human welfare and economic growth: it contributes about 25 percent to Gross Domestic Product (GDP) and employs a huge chunk of the population in SSA (FAO, 2006; AfDB, 2015). Yet, agricultural productivity is low in the region with most farmers engaged in small-scale farming. Despite the high proportion of women in agriculture, productivity is even lower for female farmers compared to their male counterparts (Palacios-Lopez, Lopez, 2014; Aguilar, et al., 2014). This is particularly the case for Nigeria, one of the largest SSA countries, where women account for $75 \%$ of the Nigeria's farming population (FMARD 2016). In some rural areas, women have practically taken over the production and processing of arable crops; being responsible for as much as $80 \%$ of staple foods (Afolabi, 2008; Ogunlela, Mukhtar, 2009). Yet, women's productive capacity in the sector remains lower than their male counterparts, possibly, impacting overall productivity adversely (SAHEL, 2016).

The rest of the paper is organised as follows; besides the introductory section, section two looks at research issues which is also the motivation for the study and a peep into existing literature. Section three presents the methodology, while section four dwells on sources and description of data used. Section five focuses on the results and section six concludes the study with policy recommendations.

\section{Research Issues}

Nigeria's agricultural sector has recently been characterised with declining growth performance and decreasing contribution to Gross Domestic Product (GDP). For instance, the agricultural gross per capita production index, using 2004-2006 as a base year, reduced from $92.2 \%$ in 2007 to $88.4 \%$ in 2013 (FAO statistics) ${ }^{2}$. While both food and non-food gross per capita agricultural production declined, non-food per capital production declined more significantly from $84.3 \%$ in 2007 to $51.8 \%$ in 2013 . Hence, the ability of agricultural sector to insulate Nigeria's economy against food insecurity and play the expected role in backward and forward linkages has been threatened. The dynamics in agricultural performance can be partly traced to increasing gender productivity gaps. In Nigeria, like many sub-Saharan African countries, women constitute a huge portion of the agricultural sector, relative to men. Yet, their productive capacity remains constrained and considerably lower than their male counterpart, possibly contributing to low overall agricultural productivity in Nigeria.

The above has drawn interest in the sources and consequences of gender differences in agricultural productivity, particularly in SSA, since the 1990s. Empirical studies have documented the presence of gender gap in agricultural productivity across Sub-Saharan Africa, and have sought to explain it (UNECA, 1982; Lopez, Romano, 2000; Hertz et al., 2009; Doss et al., 2011; Ali et al., 2015; Mukasa, Salami, 2015). The line of thought seems

2 http://faostat3.fao.org/download/Q/QI/E 
to be that female farmers have lower yields than their male counterparts largely due to differentiated: (i) access and use of agricultural inputs and land, (ii) market and credit market access, (iii) labour market discriminations in terms of off-farm wages, (iv) institutional and cultural contraints, v) physical and human capital (Peterman et al., 2011a; Palacios-Lopez and Lopez, 2014). However, many of the past studies in the literature assessing the gender disparities in agricultural productivity are fraught with conceptual and methodological flaws in assessing gender differences in agricultural productivity. Empirical evidences are limited not only by country but also by crop specificity of findings and methodological constraints (Quisumbing et al, 2011; Oseni et al., 2013; Kilic et al., 2013). This study overcomes some of these constraints by estimating crop specific models and employing a technique that caters to variations across low, medium and large scale male and female farm plot managers.

Furthermore, earlier studies find that male and female farmers have equal productive efficiency, especially, when inputs, market and credit access as well as physical and human capital are controlled for (Quisumbing, 1995; Quisumbing, Behrman, 2010). However, the role of labour market discriminations in agricultural productivity has received little attention. Despite the number of studies in the litertaure, only Palacios-Lopez and Lopez,(2014) has been found to threoretically and empirically relate gender differences in agricultural productivity to credit and labour makret imperfections. However, the authors use the decisionmaker at the household level rather than the decisionmaker at the plot level, as gender identifier. This constrains the researcher from appropriaely matching the gender of the indiviudal managing plot acitivites to agriculture input use and productivity, as it is possible that other members of the households may oversee day-to-day decision making on the plot other than the household head. Evidently, through an empricial review of literature, Peterman et al. (2011b) compare data from plot level and household head level, and find that significant gender bais at household level disappeared with plot level data. Although no attention was given to the labour market constraints, Oseni, et al. (2013), use plot level and nationally representative data across regions to analyze the structural and endowment gender differences in agricultural productivity across plot managers in the Northen and Southern parts of Nigeria. They find that women produce 28 percent less than men in the North but are barely explained by endowment factors (access to productive resources), whereas endowment factors explain most of the productive differences in the South, gender bias in agricultural produtivity is not found signifcant in the South.

Notably, the accurate diagnosis of the sources of productivity differences between male and female farmers is critical to identifying appropriate policy interventions for increasing women's productivity and overall agricultural productivity. This is particularly pertinent to Nigeria, given the renewed commitment of present government to position Nigeria's agricultural sector on a path of growth. Furthermore, the country's Federal Ministry of Agriculture and Rural Development (FMARD) in its Agricultural Promotion Policy (20162020) have identified a prioritized list of domesticated crops and animal products that will be central to tackling challenges to agricultural productivity: rice, maize, wheat, soya beans, horticulture (fruits and vegetables), sugar, poultry, and aquaculture (fish) (FMARD, 2016). Buttressing on the case for empowering women in agriculture as indicated by World Bank, 
United Nations and Africa Development Bank, Manfre, et al., (2013), add that past policy efforts at revitalizing the agricultural sector in many SSA countries have had little or no success, partly due to failure to acknowledge the role of women and the negative effects of gender inequalities on agricultural productivity

Given the aforementioned, the main objective of the study is to assess the extent of gender differences in agricultural productivity and identify its sources with the aim of enhancing gender empowerment in agriculture and improving overall agricultural productivity in Nigeria. The key hypothesis this study seeks to validate is stated as follows:

Null Hypothesis $\left(\mathrm{H}_{0}\right)$ : There is no significant gender gap in agricultural productivity and inputs access in Nigeria.

\section{Methodology}

Gender-analysis frameworks include Harvard Analytical Framework and People-Oriented Planning, Moser Framework, Gender Analysis Matrix (GAM), Capacities and Vulnerabilities Analysis Framework, Women's Empowerment (Longwe) Framework and Social Relations Approach (March et al., 1999). These gender tools have many similarities one of which is that all of them recognise and emphasise the existence of reproductive work alongside productive activities as well as need for gender empowerment and access to opportunities. However, despite many similarities, the gender frameworks differ in their scope and emphasis. For instance, the Social Relations Approach assumes that people have access to resources ${ }^{3}$ mainly through social relationships (structural relationships that create and reproduce systemic differences in the positioning of different groups of people) based on patronage and dependency, where they have to trade in their autonomy in return for security (March et al., 1999). Since the aim of this study is to investigate gender gap in agricultural productivity, it relies on Harvard Framework designed to demonstrate an economic case for allocating resources to women as well as men. The framework looks at the activity profiles of men and women, assess access to resources and benefits and looks at influencing factors causing gender division of labour, access, and control and determine different opportunities and constraints for men and women. The aim of the framework is to improve overall productivity and design more efficient policies that do not discriminate based on gender.

The Harvard Framework aligns with Oaxaca-Blinder (OB) decomposition approach that examines the sources of productivity differentials between male and female farm managers based on endowment effect, structural factors and some interaction factors, with foundations in labour economics. The decomposition method is often applied in the analyses of wage inequality such as gender wage gap and union wage gap (Oaxaca, 1973; O'Neill, O'Neill, 2006, Fortin, 2006; Fortin, et al., 2011; Aguilar, et al., 2014). In line with Harvard Framework and Palacios-Lopez and Lopez (2014), the study breaks down gender differentials in agricultural labour productivity into: 1) labour market effect, 3) credit market effect, 2) endowment effect, and 4) marginal productivity effect. The labor market effect reflects the proportion of agricultural labour productivity explained by gender differences in the number

3 Tangible and intangible resources 
of on-farm working hours - the direct impact of labour market imperfections. The credit market effect reflects the proportion of agricultural labour productivity explained by gender differences in the access to and use of purchased inputs e.g. pesticides, fertilizer, and hired labour - the direct impact of credit market constraints. The endowment effect reflects the proportion of the agricultural labour productivity explained by gender differences in the access to and control over household assets by plot manager - the long term impact of labour and credit market constraints that limits the capacity to accumulate human and physical capital. It links household characteristics to production and consumption decisions. The marginal productivity effect reflects the proportion of the agricultural labour productivity explained by gender differences in the coefficients of the various factors of production and household characteristics included in the regressions - the long term effects of labour and credit market constraints as well as institutional and cultural constraints on agricultural productivity.

Mukasa, Salami (2015) broke gender productivity gaps in Nigeria, Tanzania, and Uganda into endowment effect, structural effect and interaction effect based on OB and Daymount and Andrisani (1984) and Jann (2008). While the endowment effect reflects the definition of Palacios-Lopez and Lopez (2014), structural effect reflects the use and intensity of labor inputs in the agricultural production process and interraction effect captures the portion of productivity gap coming from simultaneous differences in both the predictors and their estimated coefficients. Most of the other previous studies such as Kilic et al. (2013) and Ali et al. (2015) use OB decomposition approach to examine the sources of productivity differentials between male and female farm managers. However, unlike Palacios-Lopez and Lopez (2014), this study critically deviates by placing emphasis on the decision maker at the plot-level, rather than household-level, as gender identifier, and applying the study in the Nigerian context. Also, it deviates from Mukasa, Salami (2015) by estimating the determinants of agricultural productivity for each gender group across major crops per unit of land. This is because farm outputs are measures in different units and their determinants may vary across crops and gender. Meanwhile, agricultural productivity models combining the two genders were also estimated to assess the overall effect of gender on farm productivity across crops.

Hence, the theoretical model adapted from Palacios-Lopez and Lopez (2014) and Harvard Framework is based on the idea of disparities in access to farm inputs, credit and productivity. Therefore, the model embodies the decisions made by different plot managers taking into account (a priori) constraints on the choice of on-farm or off-farm labor activities, which in turn affects the (ex post) allocations of labour and non-labour farm inputs. The study assumes the presence of credit market failures, gender bias in the labour market, and genderspecific off-farm time burdens. This implies that given the presence of credit constraints, for example, the decisions made by male and female plot managers and agricultural labour productivity will differ depending on their household composition and/or the opportunities available to them. 
The potential gender gap in agricultural labour productivity is defined as:

$$
\frac{f_{L}^{M}}{f_{L}^{F}}=\frac{\alpha_{1}^{F}}{\alpha_{1}^{M}(1-\Phi)} \quad \frac{\left(1+\Psi\left(Z_{h h}^{M}\right)\right)}{\left(1+\Psi\left(Z_{h h}^{F}\right)\right)}
$$

$$
\begin{array}{cc}
\text { Labour market effect } & \text { capital market effect } \\
n \text {-farm and off-farm time allocation constrain) } & \text { (liquidity constraint to purchased inputs) }
\end{array}
$$
where,

$f_{L}^{M}$ represents the marginal productivity of labour in male plots within households, and $f_{L}^{F}$ represents the marginal productivity of labour in female plots within households. $\alpha_{1}$ represents the portion of gender specific off-farm time burden that is determined by the degree of household care activities is greater than or equal to 1 , with 1 implying that the household has lower household care responsibilities. $\Psi$ (represents a function of the household plot characteristics, which may differ for male and female plot managers. $\Phi$ represents the differential treatment of the labour market towards male and female farmers. It takes values between 0 and 1, with 0 representing a non-discriminatory labour market and 1 representing a discriminatory market.

In the empirical analysis, the study first conducts pairwise comparisons of means with equal variances related to factors and labour markets between male and female plot managers and consequently estimates a combined agricultural productivity models and separate models for male (M) and female (F) plot managers as:

$$
\begin{aligned}
& \mathrm{Y}=\beta_{0}+\mathrm{L} \beta_{L}+\sum_{k} X_{k} \beta_{k}+\sum_{j} Z_{J} \delta_{j}+\lambda \mathrm{G}+\varepsilon \\
& \mathrm{Y}^{\mathrm{M}}=\beta_{0}^{M}+\mathrm{L}^{\mathrm{M}} \beta_{L}^{M}+\sum_{k} X_{k}^{M} \beta_{k}^{M}+\sum_{j} Z_{j}^{M} \delta_{j}^{M}+\varepsilon^{\mathrm{M}} \\
& Y^{F}=\beta_{0}^{F}+L^{F} \beta_{L}^{F}+\sum_{k} X_{k}^{F} \beta_{k}^{F}+\sum_{j} Z_{J}^{F} \delta_{j}^{F}+\varepsilon^{F}
\end{aligned}
$$

where,

$\mathrm{Y}\left(\mathrm{Y}^{\mathrm{M}} \mathrm{Y}^{\mathrm{F}}\right)$ represents the log value of output per hectare for male $(\mathrm{M})$ and female $(\mathrm{F})$ plot managers. Using actual output per hectare for the entire crop grown by Nigerian farmers, as used in the existing studies, is biased because the unit of measuring crop outputs varies across crops. For instance, while crops such as rice and beans are measured in bags, yam is measured in tubers. Besides, some of the input requirements for each crop also vary across crops. To overcome this problem, the study estimates for the $\operatorname{six}^{4}$ major crops grown by the sampled Nigerian farmers. Also, the study avoids using landed area cultivated, as a measure

4 This includes Cassava, Maize, Yam, Guinea Corn, Beans and Millet (see Table A2.). These crops account for $81.4 \%$ of all crops grown by Nigerian farmers. 
of agricultural output, because it does not determine productivity ${ }^{5}$. In addition, a measure of agricultural output measured by total harvest sales in monetary term is also avoided because harvest sales this season may be from past harvest and not the present harvest and there is possibility of harvest sales being influence by other factors besides input constraints such as negative demand shocks and seasonality (See Olakojo, 2016). $L$ is the number of hours of the plot manager's labor on the farm per day. $X$ is the vector of $\mathrm{k}$ which represents other inputs (improved seeds, pesticides, fertilizer, agricultural implements ${ }^{6}$, and hired labor). With respect to farm inputs, if any input shows significant negative impact on the output of any particular crop, it implies that the input in question is not an input required to produce such crop. If an input shows an insignificant positive effect, it implies that the input is important but inadequate to improve the level of output. $Z$ is the vector of household characteristics including physical and human capital (land assets, location of households and plots). $\beta_{0^{\prime}} \beta_{\text {, }}$, $\beta_{k}, \delta_{j}$ represent associated vector of intercept and slope coefficients for male and female plot managers. $\mathrm{G}$ is gender variable representing 1 if gender is male and 0 if the gender is female. $\mathcal{E}$ is the error term under the assumption that $\mathrm{E}\left(\varepsilon^{\mathrm{M}}\right)=\mathrm{E}\left(\varepsilon^{\mathrm{F}}\right)=0$.

Finally, the study estimates (1), (2) and (3) with non-parametric regression models (which uses bootstrapping technique), otherwise regarded as quantile or robust regression to deal with presence of outliers posed by the nature of heterogeneous farm production depending on whether a plot manager is a large, medium or small scale. This approach is built to deal with collinearity problem as the collinear variables are automatically dropped.

\section{Data}

The study obtains its data mainly from the Living Standards Measurement Study-Integrated Surveys on Agriculture (LSMS-ISA) for Nigeria in the wave 2 panel studies for the year 2012/2013. The Nigeria General Household Survey-Integrated Surveys on Agriculture (NGHS-ISA) data was collected in two phases; the post-planting period (September to November 2012) and post-harvest period (February to April, 2013, respectively). The survey sampled 5,000 households (about 12, 948 individuals) with representative at the national, urban/rural and the six geopolitical zones of Nigeria. The Nigeria LSMS-ISA instruments included household, agriculture, and community questionnaires covering post-planting and post-harvest periods. It also identifies the managers of plots farmed in each household, which when combined with the demographic and other components, allows one to define the gender and socio-economic characteristics of each plot manager. This would allow the study avoid the pervasive use of household-heads as default plot managers.

In this survey, all sample households were administered the multi-topic household

5 There are several reasons for this. First, a plat manager may have large landed area cultivated but the yield may be small due to certain constraints. Second, a female farm manager with larger landed area cultivated who shares her time between productive and reproductive labour may have lower farm output unlike her male counterpart.

6 The possession include Tractor, Plough, Planter, Boat, Fishing net, etc. are important in measuring farming household welfare and standards of living.

EP 2017 (64) 2 (415-435) 
questionnaire, while the households involved in agricultural activities (through ownership and/ or cultivation of land, livestock, and fishing) were administered the agriculture questionnaire. The agriculture questionnaire solicited information on land areas, physical characteristics, labour and non-labour input use, extension services, other agricultural incomes, and crop cultivation and production, with reference to rainy and dry seasons. Also, some of the relocated households were successfully tracked and interviewed using a modified questionnaire.

\section{Results and Discussion}

The characteristics of the plot managers presented in Table 1 show that the gender gaps in agricultural productivity and access gaps to relevant farm inputs in Nigeria are small. In terms of farm outputs and harvest sales, the men have relatively higher outputs and higher harvest sales but this is not significantly different from the female farm mangers. However, there is a sort of labour market imperfection against women plot managers and this is shown in the higher average wages (of N153, 824.50) paid by women plot managers above that of men plot managers (of N35, 472.49). The reason why women paid higher wages for the employed farm workers is shown in the Table 1 as well. Men spend relatively more hours (5.2 hours) on the farm than women (5.1 hours) which may be due to other reproductive household responsibilities engaging women farm managers. Hence, they are constrained to employ more hands on their farms than men as shown in the Table 1 where men employ average of 4 men plot managers and women plot mangers employ average of 5 men on the farm.

Table 1. Plot-Level Characteristics by Gender

\begin{tabular}{|l|r|r|r|r|}
\hline & \multicolumn{4}{|c|}{ Farm managers } \\
\hline Variables & Female (mean) & Male (mean) & Contrast & t-statistics \\
\hline Age of plot manager (years) & 21.195 & 26.819 & 5.624 & $24.47 * * *$ \\
\hline Location (rural=0, urban=1) & 0.103 & 0.114 & 0.011 & 1.34 \\
\hline Harvest sales (Naira) & 41673.440 & 44273.420 & 2599.980 & 1.41 \\
\hline Quantity Harvested & 477.286 & 478.345 & 1.059 & 0.01 \\
\hline Farm equip. value (Naira) & 9276.208 & 2752.572 & -6523.636 & -1.15 \\
\hline Age of farm equipment and machinery & 3.404 & 3.474 & 0.071 & 0.67 \\
\hline Farm Employment & 5.053 & 4.802 & -0.251 & -1.02 \\
\hline Wage (Naira) & 153824.500 & 35472.490 & -118352.0 & $-2.17 * *$ \\
\hline Hours spent on farm per day & 5.133 & 5.226 & 0.093 & $1.82^{*}$ \\
\hline Pesticide (not available=0, available=1) & 0.142 & 0.155 & 0.013 & 1.36 \\
\hline Cost of pesticide (Naira) & 3871.538 & 3445.802 & -425.737 & -1.17 \\
\hline Herbicides (not available=0, available=1) & 0.273 & 0.274 & 0.001 & 0.07 \\
\hline Cost of herbicide (Naira) & 4639.308 & 3730.753 & -908.555 & $-1.72 *$ \\
\hline $\begin{array}{l}\text { Farm equi./machine (not available=0, } \\
\text { available=1) }\end{array}$ & 0.249 & 0.254 & 0.005 & 0.43 \\
\hline Costs of farm equip/machine. (Naira) & 13958.590 & 14175.400 & 216.803 & 0.06 \\
\hline Fertilizer (Don't use=0, use=1) & 0.384 & 0.372 & -0.013 & -0.98 \\
\hline
\end{tabular}




\begin{tabular}{|l|r|r|r|r|}
\hline Free fertilizer (No=0, Yes=1) & 0.028 & 0.021 & -0.008 & -1.15 \\
\hline Purchased fertilizer (No=0, Yes=1) & 0.904 & 0.901 & -0.003 & -0.26 \\
\hline Cost of fertilizer (Naira) & 2011.324 & 1854.459 & -156.865 & -0.58 \\
\hline Free seed (not available=0, available=1) & 0.018 & 0.022 & 0.004 & 1.52 \\
\hline Purchase seed (No=0, Yes=1) & 0.149 & 0.149 & 0.001 & 0.08 \\
\hline Cost of seed purchased (Naira) & 2841.107 & 2623.711 & -217.396 & -0.69 \\
\hline Animal traction (Don't use=0, use=1) & 0.193 & 0.205 & 0.012 & 1.15 \\
\hline Cost of animal traction (Naira) & 4280.847 & 4597.122 & 316.275 & 0.75 \\
\hline Land (Don't have access=0, have access=1) & 0.651 & 0.676 & 0.024 & $1.88^{*}$ \\
\hline Irrigated land & 0.016 & 0.012 & -0.003 & -1.09 \\
\hline Literacy & 0.585 & 0.626 & 0.042 & 0.84 \\
\hline
\end{tabular}

Source: Computed using STATA

Note: ***,*** implies significant at $10 \%, 5 \%$, and $1 \%$ respectively

Meanwhile, the age of men and women plot managers significantly differ. While the average age of men plots managers is 26.82 years that of the women pot managers is 21.20 years. This has implications in terms of farming experience and farm output. That is, men plot managers are likely to have more farming experience than women plot mangers. Overall, the access of both men and women plot managers to government support farm inputs is very low. For instance, only $14 \%$ and $16 \%$ of sampled female and male plot managers indicate that they have access to pesticides. It is worse in the case of free seed availability where only $1.8 \%$ and $2.2 \%$ of female and male pot managers respectively indicate access. The situation is similar in terms of access to irrigated lands. However, most of the inputs used on the farm are out of pocket purchase. For instance, while only $2.8 \%$ and $2.1 \%$ of female and male plot managers respectively indicate access to free fertilizers, $90.4 \%$ and $90.1 \%$ of female and male plot managers respectively indicate that they purchase fertilizers. In terms of gender disparities in access to farm inputs, on the average men have higher level of access, although with no significant difference. Of particular important is access to land, men plot managers do have higher access to land than women pot managers but this is only significant at $10 \%$ level.

Further, the important of the descriptive statistics, presented in Table 2, is to assess the nature of the data to be used in subsequent estimations in order to guide against model misspecifications. The standard deviations (stds) and coefficients of variations (CVs) indicate that all key variables are not normally distributed given the values of stds and CVs above 0.5 . In other words, these variables exhibit significant skewness. This implies that some of the farmers are small scale farmers, some are medium scale farmers and some are large scale farmers. Given the characteristics of the key variables, employing linear regression will yield biased estimations; hence the justification for employing nonparametric or robust regression techniques. 
Table 2. Description of selected variables

\begin{tabular}{|c|c|c|c|c|c|c|c|c|c|c|}
\hline stats & $\begin{array}{l}\text { Harvest } \\
\text { sales } \\
\text { (Naira) }\end{array}$ & $\begin{array}{l}\text { Quantity } \\
\text { Harvested }\end{array}$ & $\begin{array}{l}\text { Farm } \\
\text { employment } \\
\text { (Number of } \\
\text { employees) }\end{array}$ & $\begin{array}{l}\text { Wage } \\
\text { (Naira) }\end{array}$ & $\begin{array}{l}\text { Cost of } \\
\text { pesticides } \\
\text { (Naira) }\end{array}$ & $\begin{array}{l}\text { Cost of } \\
\text { herbicides } \\
\text { (Naira) }\end{array}$ & $\begin{array}{l}\text { Cost of } \\
\text { farm } \\
\text { equipment } \\
\text { (Naira) }\end{array}$ & $\begin{array}{l}\text { Cost of } \\
\text { fertilizer } \\
\text { (Naira) }\end{array}$ & $\begin{array}{l}\text { Cost of seed } \\
\text { purchased } \\
\text { (Naira) }\end{array}$ & $\begin{array}{l}\text { Cost of } \\
\text { renting } \\
\text { animals } \\
\text { for } \\
\text { traction } \\
\text { (Naira) }\end{array}$ \\
\hline $\min$ & 0 & 0 & 0 & 0 & 70 & 100 & 200 & 0 & 10 & 150 \\
\hline $\max$ & 2600000 & 600000 & 300 & 70000000 & 72000 & 270000 & 150000 & 60000 & 150000 & 70000 \\
\hline mean & 42941.36 & 477.8016 & 4.931576 & 96458.06 & 3656.643 & 4196.255 & 14066.14 & 1936.595 & 2734.272 & 4434.293 \\
\hline sd & 88534.65 & 7612.779 & 9.414036 & 2095419 & 5282.733 & 10341.65 & 20346.75 & 5984.502 & 6350.216 & 5038.818 \\
\hline $\mathrm{cv}$ & 2.061757 & 15.93293 & 1.90893 & 21.72362 & 1.444695 & 2.464496 & 1.446505 & 3.090218 & 2.322452 & 1.13633 \\
\hline
\end{tabular}

Source: Computed using STATA

Moreo ver, estimates of farm outputs indicate that the selected inputs have less significant impact on the farm outputs across crops. The reason is traceable to crude farm equipment many farmers still use in Nigeria. For instance, $81 \%$ of sampled famers use hoes and cutlasses.

Table 3. Estimates of Farm Outputs (Cassava and Maize)

\begin{tabular}{|c|c|c|c|c|c|c|c|c|c|c|c|c|}
\hline \multirow{3}{*}{$\begin{array}{l}\text { logqtyharv } \\
\text { estd }\end{array}$} & \multicolumn{6}{|c|}{ Cassava } & \multicolumn{6}{|c|}{ Maize } \\
\hline & \multicolumn{2}{|c|}{ Aggregate } & \multicolumn{2}{|c|}{ Female Farmer } & \multicolumn{2}{|c|}{ Male Farmer } & \multicolumn{2}{|c|}{ Aggregate } & \multicolumn{2}{|c|}{ Female Farmer } & \multicolumn{2}{|c|}{ Male Farmer } \\
\hline & Coef. & $\mathrm{t}$ & Coef. & $\mathrm{t}$ & Coef. & $\mathrm{t}$ & Coef. & $\mathrm{t}$ & Coef. & $t$ & Coef. & $\mathrm{t}$ \\
\hline \multicolumn{13}{|l|}{$\begin{array}{l}\text { Quantile } \\
\mathbf{2 5}\end{array}$} \\
\hline $\begin{array}{l}\text { logavhrsp } \\
\text { entpd }\end{array}$ & 0.497 & $1.91^{*}$ & 0.413 & 0.38 & 0.024 & 0.05 & 0.106 & -0.25 & 0.181 & 0.31 & $\begin{array}{r}- \\
0.765 \\
\end{array}$ & -1.03 \\
\hline $\begin{array}{l}\text { logtotalem } \\
\mathrm{p}\end{array}$ & -0.204 & -1.14 & -0.141 & -0.27 & $\begin{array}{r}- \\
0.238 \\
\end{array}$ & -0.79 & 0.003 & 0.02 & 0.336 & $\begin{array}{r}2.25 * \\
* \\
\end{array}$ & 0.173 & 0.86 \\
\hline $\begin{array}{l}\text { machinea } \\
\text { va }\end{array}$ & 0.341 & 1.03 & 0.215 & 0.34 & 0.468 & 1.42 & $\begin{array}{r}- \\
0.417 \\
\end{array}$ & -1.52 & $\begin{array}{r}- \\
0.389 \\
\end{array}$ & -0.9 & $\begin{array}{r}- \\
0.969 \\
\end{array}$ & $-2.18 * *$ \\
\hline pesticisav & -0.503 & -1.31 & -0.572 & -0.9 & $\begin{array}{r}- \\
0.588\end{array}$ & -1.39 & $0.300^{-}$ & -0.57 & 0.151 & 0.36 & $\begin{array}{r}- \\
0.637 \\
\end{array}$ & -0.85 \\
\hline herbiciava & 0.978 & $\begin{array}{r}2.41 * \\
* \\
\end{array}$ & 1.013 & 1.06 & 1.094 & $\begin{array}{r}2.09 * \\
*\end{array}$ & 0.765 & $\begin{array}{r}2.63 * \\
* \\
\end{array}$ & 0.674 & $\begin{array}{r}2.49 * \\
* \\
\end{array}$ & 0.765 & $2.41^{* *}$ \\
\hline fertiuse & 0.124 & 0.3 & 0.211 & 0.36 & 0.135 & 0.25 & 0.350 & -0.93 & 0.302 & -0.61 & $\begin{array}{r}- \\
0.747\end{array}$ & -1.39 \\
\hline freeseed & 0.411 & 1.07 & 0.352 & 0.3 & - & - & 2.145 & $\begin{array}{r}2.34^{*} \\
*\end{array}$ & $\begin{array}{r}- \\
1.709\end{array}$ & -1.62 & $\begin{array}{r}- \\
1.508 \\
\end{array}$ & -0.88 \\
\hline $\begin{array}{l}\text { animaltrac } \\
\text { tnue }\end{array}$ & -0.393 & -1.01 & -0.486 & -0.85 & $\begin{array}{r}- \\
0.131 \\
\end{array}$ & -0.22 & 0.281 & -0.56 & 0.507 & 1.56 & $\begin{array}{r}- \\
0.259\end{array}$ & -0.44 \\
\hline $\begin{array}{l}\text { irrigatedpl } \\
\text { ot }\end{array}$ & -0.828 & -0.41 & -0.785 & -0.39 & $\begin{array}{r}- \\
0.046\end{array}$ & -0.02 & 2.056 & 0.89 & 4.406 & $\begin{array}{r}2.17 * \\
* \\
\end{array}$ & $\begin{array}{r}- \\
1.518\end{array}$ & -0.58 \\
\hline landaccess & -0.042 & -0.15 & -0.218 & -0.25 & 0.201 & 0.43 & 0.588 & $\begin{array}{r}2.06 * \\
*\end{array}$ & 0.027 & 0.08 & 1.359 & $2.64 * *$ \\
\hline locatn & -0.609 & -1.52 & -0.734 & -0.59 & $\begin{array}{r}- \\
0.928\end{array}$ & -0.5 & $\begin{array}{r}- \\
0.433 \\
\end{array}$ & -0.98 & $\begin{array}{r}- \\
0.327\end{array}$ & -0.67 & $\begin{array}{r}- \\
0.043\end{array}$ & -0.07 \\
\hline logage & 0.055 & 0.45 & 0.083 & 0.26 & 0.062 & -0.28 & $\begin{array}{r}- \\
0.005 \\
\end{array}$ & -0.03 & $\begin{array}{r}- \\
0.236 \\
\end{array}$ & -0.97 & $\begin{array}{r}- \\
0.017 \\
\end{array}$ & -0.08 \\
\hline sex & -0.408 & -1.2 & - & - & - & - & 0.332 & 1.17 & - & - & - & - \\
\hline cons & 1.465 & $\begin{array}{r}2.22^{*} \\
*\end{array}$ & 1.526 & 0.84 & 1.959 & 2.01 & 3.017 & $\begin{array}{r}3.86^{*} \\
* \\
\end{array}$ & 3.200 & $\begin{array}{r}3.43 * \\
* \\
\end{array}$ & 4.928 & $3.43^{* *}$ \\
\hline Pseudo $\mathrm{R}^{2}$ & \multicolumn{2}{|c|}{0.09} & \multicolumn{2}{|c|}{0.09} & \multicolumn{2}{|c|}{0.09} & \multicolumn{2}{|r|}{0.06} & \multicolumn{2}{|r|}{0.07} & \multicolumn{2}{|r|}{0.13} \\
\hline $\begin{array}{l}\text { Quantile } \\
\mathbf{5 0}\end{array}$ & & & & & & & & & & & & \\
\hline
\end{tabular}




\begin{tabular}{|c|c|c|c|c|c|c|c|c|c|c|c|c|}
\hline $\begin{array}{l}\text { logavhrsp } \\
\text { entyd }\end{array}$ & 0.310 & 0.62 & 1289 & 1.53 & 0.000 & 0 & 0.401 & -0.85 & 0.382 & 0.62 & 0.713 & -0.88 \\
\hline $\begin{array}{l}\text { logtotalem } \\
\mathrm{p}\end{array}$ & -0.082 & -0.4 & -0.082 & -0.15 & 0.108 & 0.28 & 0.254 & 0.79 & 0.483 & -1.26 & 0.550 & $196 * *$ \\
\hline $\begin{array}{l}\text { machinea } \\
\text { va }\end{array}$ & 0.126 & 0.26 & -0.407 & -0.65 & 0.444 & 0.79 & 2.086 & $\begin{array}{r}4.21 * \\
* * \\
\end{array}$ & 1.926 & $\begin{array}{r}3.56^{*} \\
* * \\
\end{array}$ & 2.434 & $3.77^{* * *}$ \\
\hline pesticisav & -0.709 & -1.31 & -0.583 & -0.71 & 0.603 & -0.93 & 0.101 & -0.15 & 0.489 & 0.59 & 0.094 & -0.09 \\
\hline herbiciava & 1.049 & $1.88^{*}$ & 0.361 & 0.36 & 1.340 & $\begin{array}{r}2.43^{*} \\
*\end{array}$ & 1.042 & $\begin{array}{r}2.25 * \\
*\end{array}$ & 0.805 & -1.35 & 1.059 & $1.72 *$ \\
\hline fertiuse & -0.206 & -0.54 & -0.385 & -0.47 & 0.214 & -0.44 & 0.471 & 0.69 & 0.588 & 0.92 & 0.141 & -0.17 \\
\hline freeseed & -1.007 & -1.6 & -2.016 & -1.15 & & & 3.761 & $\begin{array}{r}2.22 * \\
* \\
\end{array}$ & 4.185 & -1.66 & 3.002 & -1.17 \\
\hline $\begin{array}{l}\text { animaltrac } \\
\text { tnuse }\end{array}$ & -0.054 & -0.1 & 0.203 & 0.2 & 0.159 & 0.19 & 0.951 & -1.61 & 1.300 & -1.53 & 0.173 & -0.15 \\
\hline $\begin{array}{l}\text { irigatedpl } \\
\text { ot }\end{array}$ & -0.602 & -0.37 & -0.715 & -0.27 & 0.424 & -0.16 & 1.301 & 0.75 & 1.649 & 1.25 & 0.228 & 0.09 \\
\hline landaccess & 0.207 & 0.67 & 0.182 & 0.2 & 0.292 & -0.61 & $\begin{array}{r}- \\
0.275 \\
\end{array}$ & -0.72 & 0.313 & 0.52 & 0.474 & -0.85 \\
\hline locatn & -0.818 & -1.33 & -0.973 & -0.62 & 1.407 & -0.63 & 1.533 & $\begin{array}{r}3.13 * \\
* \\
\end{array}$ & $1.589^{\circ}$ & -2.5 & 1.295 & -1.41 \\
\hline logage & 0.134 & 0.87 & 0.259 & 0.6 & 0.247 & 0.95 & 0.223 & 1.05 & 0.091 & 0.3 & 0.380 & 1.57 \\
\hline sex & -0.642 & -1.62 & & & & & 0.201 & 0.49 & & & & \\
\hline cons & 2.346 & $\begin{array}{r}2.57^{*} \\
*\end{array}$ & 1.033 & 1.04 & 1.851 & $\begin{array}{r}2.48^{*} \\
* \\
\end{array}$ & 4.744 & $\begin{array}{r}3.99 * \\
*\end{array}$ & 4.694 & $\begin{array}{r}3.37 * \\
*\end{array}$ & 4.553 & $295^{* *}$ \\
\hline Pseudo $\mathrm{R}^{2}$ & \multicolumn{2}{|c|}{0.07} & \multicolumn{2}{|c|}{0.09} & \multicolumn{2}{|c|}{0.09} & \multicolumn{2}{|c|}{0.12} & \multicolumn{2}{|c|}{0.12} & \multicolumn{2}{|c|}{0.16} \\
\hline \multicolumn{13}{|l|}{$\begin{array}{l}\text { Quantile } \\
75\end{array}$} \\
\hline $\begin{array}{l}\text { logavhrsp } \\
\text { entpd }\end{array}$ & 0.753 & 1.66 & 1.158 & 1.11 & 0.108 & -0.12 & 0.031 & 0.11 & 0.225 & 0.59 & 0.460 & -1 \\
\hline $\begin{array}{l}\text { logtotalem } \\
\mathrm{p}\end{array}$ & 0.196 & 0.64 & 0.421 & 0.78 & 0.038 & -0.06 & 0.018 & 0.1 & 0.065 & -0.34 & 0.197 & 0.98 \\
\hline $\begin{array}{l}\text { machinea } \\
\text { va }\end{array}$ & 0.750 & 0.63 & -0.479 & -0.6 & 1.069 & 1.07 & 2.983 & $\begin{array}{r}8.02^{*} \\
* *\end{array}$ & 2.815 & $\begin{array}{r}4.21^{*} \\
* *\end{array}$ & 3.266 & $8.11^{* * *}$ \\
\hline pesticisav & -1.039 & -1.27 & -0.504 & -0.59 & 1.063 & -1.28 & 0.062 & -0.16 & 0.491 & 0.55 & 0.348 & -0.57 \\
\hline herbiciava & 0.603 & 0.8 & -0.545 & -0.53 & 1.150 & 0.82 & $\begin{array}{r}- \\
0.554 \\
\end{array}$ & $1.91^{*}$ & 0.991 & $\begin{array}{r}- \\
1.77^{*}\end{array}$ & $0.442^{-}$ & -1.17 \\
\hline fertiuse & -0.399 & -0.71 & -1.138 & -1.4 & $0.830^{-}$ & -0.71 & 0.537 & $1.75^{*}$ & 0.661 & $1.73^{*}$ & 0.118 & 0.2 \\
\hline freeseed & -3.382 & $\begin{array}{r}- \\
2.35^{*} \\
*\end{array}$ & -4.268 & -1.65 & - & - & 3.055 & $1.73^{*}$ & 5.900 & $1.93 *$ & 3.002 & 1.11 \\
\hline $\begin{array}{l}\text { animaltrac } \\
\text { tnue }\end{array}$ & 0.165 & 0.34 & 0.674 & 0.79 & 1.061 & 0.66 & 0.849 & $\begin{array}{r}2.15^{*} \\
* \\
\end{array}$ & 1.458 & $1.83^{*}$ & & -0.26 \\
\hline $\begin{array}{l}\text { imigatedpl } \\
\text { ot }\end{array}$ & 2.065 & 1.19 & 2539 & 0.71 & 2.114 & 1.02 & 0.451 & 0.29 & 0.245 & 0.19 & 0.226 & 0.12 \\
\hline landaccess & 0.388 & 1.2 & 1.406 & $\begin{array}{r}1.89 \\
*\end{array}$ & 0.004 & -0.01 & 0.184 & 0.81 & 0.178 & -0.67 & 0.169 & -0.49 \\
\hline locatn & 0.157 & 0.1 & -0.717 & -0.39 & 1.981 & -0.69 & $\begin{array}{r}- \\
0.635 \\
\end{array}$ & -0.81 & 2.180 & $\begin{array}{r}2.06^{*} \\
* \\
\end{array}$ & 0.188 & -0.19 \\
\hline logage & 0.031 & 0.1 & 0.207 & 0.55 & 0.307 & 0.74 & 0.185 & 159 & 0.192 & 1.14 & 0.135 & 0.68 \\
\hline sex & -1.059 & $1.75^{*}$ & - & - & - & - & 0.069 & -0.23 & & & & \\
\hline cons & 3.193 & $\begin{array}{r}2.62^{*} \\
*\end{array}$ & 1.783 & 0.96 & 3.277 & 1.54 & 5.822 & $\begin{array}{r}7.99 * \\
* *\end{array}$ & 5.814 & $\begin{array}{r}7.12 * \\
* * \\
\end{array}$ & 6.777 & $7.39 * * *$ \\
\hline Pseudo $\mathrm{R}^{2}$ & & 0.08 & 0.12 & & 0.11 & & & 0.18 & 0.21 & & 0.17 & \\
\hline Obs & & 208 & & 101 & & 107 & & 342 & & 101 & & 107 \\
\hline
\end{tabular}

Source: Computed using STATA

Note: $* * *, * * *$ implies significant at $10 \%, 5 \%$, and $1 \%$ respectively. - implies variables dropped due to collinearity problem. 
The estimate of cassava output among the small scale farmers (quantile 25) indicated in Table 3 shows that herbicides availability is important in improving cassava production. However, it is significant for male farmers with elasticity of 1.09. That is, if herbicides are available cassava production will improve by $1.09 \%$ among low scale male farmers. This implies that relative access to herbicides by male plot managers (as indicated in Table 1) increases output of cassava output of male plot managers at the expense of female plot managers. Further, herbicides are also important in maize production. The estimations including both plot managers, male and female small scale plot managers (quantile 25) indicate significant impact with coefficient of male plot managers (0.76) marginally higher than that of female plot managers (0.674). While free seed availability is not significant in cassava production as expected, it improves maize production by $2.15 \%$ in the estimations involving both genders small scale plot managers. Likewise, land access is important in producing maize. The results show that land access improves quantity of maize produced by $1.36 \%$ among small scale male farmers but it was not found significantly improving maize output among female small scale plot managers (Table 3 ).

Among the medium scale farmers (quantile 50), herbicides is only significant in improving cassava production among the male plot managers with elasticity of $1.34 \%$. In the case of medium scale maize farmers, availability of machine is found to be significant in all the three estimations involving both plot managers, male and female medium scale plot managers. However, the coefficient of male plot managers (2.432) is larger than that of female plot managers (1.926). This means that availability of machines improve output of maize more significantly among male farm managers. Besides, free seed and herbicides is also found to significantly improve output of maize among the medium scale farmers. However, production of maize reduces by $1.53 \%$ as location tends to be urban among the medium scale farmers (Table 3 ). This implies medium scale maize farming is often carried out in rural areas.

For the large scale cassava farmers (quantile 75), gender only reduces cassava production marginally by $1.06 \%$ and this is only significant at $10 \%$ level. That is, as gender tends to be female plot managers, output of cassava reduces by $1.06 \%$. Meanwhile, free seed shows negative impact on cassava productivity. This implies that cassava production does not use seed or substitutability of cassava production for other crops whose free seeds are available. Location also reduces maize production significantly but this is only relevant among the male large scale farmers. That is, production reduces by $2.18 \%$ if the farm location is in urban areas among the large scale farmers.

In the case of yam and guinea corn presented in Table 4, it is realized that none of the inputs enhances output of guinea corn but as location tends to urban its output reduces by $2.51 \%$. This implies that poor performance of guinea corn relating to the key inputs. However, yam output is driven mainly by availability of pesticides and fertilizer among the low scale farmers but the impact is only significant among low scale male plot managers. Herbicides availability reduces yam output significantly among the low scale farmers. 
Table 4. Estimates of Farm Outputs (Yam and Guinea Corn)

\begin{tabular}{|c|c|c|c|c|c|c|c|c|c|c|c|c|}
\hline \multirow[b]{3}{*}{ logqtyharvested } & \multicolumn{6}{|c|}{ Yam } & \multicolumn{6}{|c|}{ Guinea corn } \\
\hline & \multicolumn{2}{|c|}{ Aggregate } & \multicolumn{2}{|c|}{$\begin{array}{l}\text { Female } \\
\text { Farmer }\end{array}$} & \multicolumn{2}{|c|}{ Male Farmer } & \multicolumn{2}{|c|}{ Aggregate } & \multicolumn{2}{|c|}{ Female Farmer } & \multicolumn{2}{|c|}{ Male Farmer } \\
\hline & Coef. & $\mathrm{t}$ & Coef. & $\mathrm{t}$ & Coef. & $\mathrm{t}$ & Coef. & $t$ & Coef. & $\mathrm{t}$ & Coef. & $\mathrm{t}$ \\
\hline \multicolumn{13}{|l|}{ Quantile 25} \\
\hline logavhrspentpd & -0.951 & -1.47 & -0.714 & -1.11 & -0.085 & -0.14 & 1.343 & 1.35 & 1.365 & 1.4 & 0.190 & 0.17 \\
\hline logtotalemp & 0.635 & 1.45 & 0.471 & 1.16 & 0.121 & 0.21 & -0.304 & -0.58 & -0.780 & -0.96 & -0.192 & -0.28 \\
\hline machineava & -0.482 & -0.69 & -0.736 & -0.81 & 0.387 & 0.53 & 0.207 & 0.26 & 0.578 & 0.41 & 0.591 & 0.71 \\
\hline pesticisav & 1.330 & $2.09 * *$ & 0.772 & 0.91 & 1.294 & $2.47 * *$ & 0.625 & 0.59 & 0.605 & 0.26 & -1.132 & -0.67 \\
\hline herbiciava & -1.339 & $-2.49 * *$ & -1.429 & -1.82 & 0.895 & 0.74 & 0.675 & 0.86 & 0.853 & 0.51 & 0.566 & 0.63 \\
\hline fertiuse & 1.339 & $2.55^{* *}$ & 0.617 & 0.94 & 2.583 & $3.32 * *$ & -0.379 & -0.33 & 0.485 & 0.25 & 0.941 & 1.27 \\
\hline freeseed & 2.109 & 1.02 & & & 1.925 & 1.1 & 0.388 & 0.19 & 4.583 & 1.16 & 2.135 & 1.02 \\
\hline animaltractnuse & -0.823 & -1.52 & -1.195 & -1.6 & -0.342 & -0.47 & 0.326 & 0.2 & 0.604 & 0.35 & -3.038 & -1.84 \\
\hline irrigatedplot & 1.060 & 0.64 & -1.976 & -0.69 & 2.054 & $3.24^{* *}$ & 0.249 & 0.13 & -0.296 & -0.15 & -2.417 & -1.35 \\
\hline landaccess & -0.104 & -0.22 & 0.434 & 0.61 & -0.471 & -0.71 & -0.020 & -0.04 & 0.251 & 0.21 & 0.243 & 0.2 \\
\hline locatn & -0.522 & -0.6 & -0.473 & -0.57 & 0.174 & 0.2 & -2.505 & $-2.41 * *$ & -0.886 & -0.32 & -3.159 & -1.46 \\
\hline logage & -0.249 & -1.1 & -0.255 & -0.82 & -0.156 & -0.5 & -0.196 & -0.51 & 0.374 & 0.5 & -0.194 & -0.65 \\
\hline $\operatorname{sex}$ & -0.375 & -0.78 & - & - & - & - & -0.873 & -1.27 & - & - & - & - \\
\hline _cons & 5.273 & $3.14^{* *}$ & 5.324 & $4.26^{* * *}$ & 2.896 & $2.21^{* *}$ & 4.011 & $2.44^{* *}$ & 2.011 & 0.69 & 5.118 & $2.92^{* *}$ \\
\hline Pseudo $\mathrm{R}^{2}$ & & 0.08 & & 0.10 & & 0.21 & & 0.12 & & 0.14 & & 0.23 \\
\hline \multicolumn{13}{|l|}{ Quantile 50} \\
\hline logavhrspentpd & -0.501 & -1.2 & -0.896 & -1.07 & -0.690 & -1.48 & 0.733 & 1.31 & 0.703 & 1.1 & -0.138 & -0.22 \\
\hline logtotalemp & 0.591 & $2.38^{* *}$ & 0.533 & $2.48^{* *}$ & 0.541 & $2.06^{* *}$ & -0.326 & -1.12 & -0.386 & -1.16 & -0.736 & -1.35 \\
\hline machineava & -0.085 & -0.18 & -0.073 & -0.11 & -0.069 & -0.11 & -0.462 & -1.39 & -0.449 & -0.95 & 0.004 & 0.01 \\
\hline pesticisav & 0.910 & 1.98 & 0.902 & 1.65 & 0.685 & 1.23 & 0.165 & 0.27 & -0.037 & -0.04 & -0.627 & -0.34 \\
\hline herbiciava & -0.665 & -1.62 & -1.015 & -2.06 & 0.436 & 0.59 & 0.297 & 0.89 & 0.922 & 1.45 & 0.430 & 0.8 \\
\hline fertiuse & 0.767 & $1.97^{* *}$ & 0.660 & 1.65 & 1.197 & $2.28^{* *}$ & 0.394 & 0.87 & 0.748 & 1.27 & 0.223 & 0.49 \\
\hline freeseed & 1.306 & 0.96 & - & - & 1.143 & 0.79 & 1.009 & 0.84 & 2.507 & $1.69^{*}$ & 1.643 & 1.47 \\
\hline animaltractnuse & -0.271 & -0.73 & -0.547 & -1.09 & 0.031 & 0.07 & -0.225 & -0.57 & -0.622 & -1.15 & -0.776 & -0.44 \\
\hline irrigatedplot & 0.225 & 0.18 & -4.122 & $-1.69 *$ & 0.864 & 0.96 & -0.734 & -0.67 & -0.657 & -0.68 & -2.330 & $-2.11^{* *}$ \\
\hline landaccess & -0.324 & -0.93 & 0.052 & 0.09 & -0.422 & -0.96 & 0.183 & 0.45 & 0.624 & 1.36 & -0.373 & -0.99 \\
\hline locatn & 0.094 & 0.26 & 0.195 & 0.28 & 0.367 & 0.43 & -1.618 & -1.59 & -0.802 & -0.61 & -2.232 & -1.45 \\
\hline logage & 0.043 & 0.24 & 0.019 & 0.09 & -0.024 & -0.07 & -0.144 & -0.72 & 0.138 & 0.51 & -0.087 & -0.36 \\
\hline $\operatorname{sex}$ & -0.350 & -1.03 & - & - & - & - & -0.165 & -0.51 & - & - & - & - \\
\hline cons & 5.392 & $4.9^{* * *}$ & 6.020 & $3.69^{* *}$ & 5.244 & $3.03^{* *}$ & 5.539 & $4.78^{* * *}$ & 4.383 & $2.69^{* *}$ & 7.486 & $9.39 * * *$ \\
\hline Pseudo $\mathrm{R}^{2}$ & & 0.10 & & 0.11 & & 0.13 & & 0.06 & & 0.12 & & 0.08 \\
\hline \multicolumn{13}{|l|}{ Quantile 75} \\
\hline logavhrspentpd & -0.629 & -1.38 & -0.978 & -1.12 & -0.010 & -0.02 & -0.107 & -0.27 & 0.350 & 0.58 & -0.360 & -1 \\
\hline logtotalemp & 0.553 & $3.15^{* *}$ & 0.570 & $3.82 * * *$ & 0.580 & $2.33^{* *}$ & -0.025 & -0.12 & -0.002 & 0.00 & -0.262 & -0.6 \\
\hline machineava & -0.082 & -0.19 & 0.104 & 0.2 & -0.147 & -0.23 & -0.302 & -0.77 & -0.131 & -0.19 & -0.344 & -0.78 \\
\hline pesticisav & 0.254 & 0.77 & 0.097 & 0.19 & 0.252 & 0.35 & 0.349 & 0.55 & 0.869 & 0.74 & 0.356 & 0.3 \\
\hline herbiciava & -0.330 & -0.92 & -0.586 & -0.94 & -0.142 & -0.22 & 0.040 & 0.09 & 0.896 & 1.56 & 0.257 & 0.63 \\
\hline fertiuse & 0.643 & $2.19 * *$ & 0.624 & 1.3 & 0.706 & 1.14 & 0.377 & 0.91 & 0.462 & 1.18 & -0.239 & -0.47 \\
\hline freeseed & 0.023 & 0.02 & - & - & 0.368 & 0.44 & 0.464 & 0.44 & 0.973 & 0.61 & 0.419 & 0.57 \\
\hline animaltractnuse & -0.123 & -0.42 & -0.366 & -0.8 & 0.188 & 0.43 & -0.262 & -0.78 & -0.118 & -0.23 & -0.599 & -0.43 \\
\hline
\end{tabular}




\begin{tabular}{|l|r|r|r|r|r|r|r|r|r|r|r|r|}
\hline irrigatedplot & 0.163 & 0.17 & 0.445 & 0.24 & 0.761 & 1.14 & -0.645 & -1.14 & -0.058 & -0.06 & -0.911 & -1.23 \\
\hline landaccess & -0.153 & -0.47 & -0.026 & -0.06 & -0.183 & -0.24 & 0.024 & 0.08 & 0.145 & 0.47 & -0.023 & -0.06 \\
\hline locatn & -0.043 & -0.15 & 0.420 & 0.63 & -0.533 & -1.02 & -0.785 & -1.15 & 0.232 & 0.24 & -0.357 & -0.29 \\
\hline logage & -0.105 & -0.57 & -0.129 & -0.53 & 0.006 & 0.02 & -0.079 & -0.64 & 0.234 & 1 & -0.047 & -0.31 \\
\hline sex & 0.122 & 0.51 & - & - & - & - & -0.063 & -0.18 & - & - & - & - \\
\hline cons & 7.048 & $6.99^{* * *}$ & 7.570 & $7.99^{* * *}$ & 5.614 & $4.34^{* * *}$ & 7.029 & $9.86^{* * *}$ & 4.992 & $3.73^{* * *}$ & 7.801 & $8.31^{* * *}$ \\
\hline Pseudo R & & 0.07 & & 0.10 & & 0.06 & & 0.06 & & 0.14 & 0.07 \\
\hline Obs & & 314 & & 160 & & 154 & & 175 & & 84 & 91 \\
\hline
\end{tabular}

Source: Computed using STATA

Note: $* * *, * * *$ implies significant at $10 \%, 5 \%$, and $1 \%$ respectively. - implies variables dropped due to collinearity problem.

This implies that farmers use multi-cropping technique such that availability of herbicides does not necessarily improve yam output but may improve other crops' output. Also, it may imply substitutability of yam for other crops whose inputs (such as herbicides) are easily available. In addition, availability of irrigated plots improves yam production by $2.05 \%$ among the small scale male plot managers but was not found significant among their female plot managers counterpart.

Among the medium scale farmers, farm employment and fertilizer use are the key variables driving yam output. While farm employment is significant for both male and female plot managers, the coefficient of male plot managers $(0.54 \%)$ is marginally higher than that of female plot managers $(0.53 \%)$. This means that male plot managers' employees are more productive than female plot managers. The reason may be because male spent longer hours on the farm and thus able to monitor workers than their female counterpart. Another gender gap in yam production surfaced in the coefficient of fertilizer use that is significant (approximately $1.20 \%)$ in the case of male farmers and insignificant $(0.66 \%)$ in the case of female plot managers. Similar results to the medium scale farmers are obtained with large scale farmers.

With regards to beans and millet, hours spent on farm (improve beans output by $1.02 \%$ ) and the use of animal traction (improve beans output by $0.66 \%$ ) are significant determinants of beans among the low scale farmers, while pesticides (improve millet output by $1.38 \%$ ) and free seed (improve millet output by $1.66 \%$ ) availability are significant determinants of millet output among the low scale farmers. Significant gender gaps were not established among the low scale beans and millet farmers. Among the medium scale farmers, availability of herbicides improves output of beans by $0.46 \%$, while farm employment is the key driver of millet output among medium scale male plot managers. Finally, larger scale beans farming is driven positively by machine availability $(0.50 \%)$, fertilizer use $(0.38 \%)$ and land access $(0.51 \%)$. Meanwhile, female plot managers' hour spent on farm improves beans output significantly among the large scale female beans farmers $(0.70 \%)$ but no significant relationship could be established in the case of large scale male beans farmers. However, farm employment is a significant determinant of millet among the large scale male plot managers but not among their female counterpart. 
Overall, gender productivity gaps in the selected crops vary. While it is mild on the aggregate implying that both male and female face similar input constraints resulting in low farm productivity, the gender productivity gaps is more pronounced in certain crops than other given the variation in responsiveness of farm outputs to inputs used and other variables. The productivity gaps are particularly traceable to farming experience in favour of men and labour market imperfection which is biased against women. This is in line with previous studies such as UNECA (1982), Lopez and Romano (2000), Hertz et al. (2009), Doss et al. (2011), Peterman et al. (2011a), Palacios-Lopez and Lopez (2014), Ali et al. (2015) and Mukasa and Salami (2015) which found that female farmers have lower yields than their male counterparts largely due to differences in access and use of agricultural inputs and land, market and credit market access, labour market discriminations in terms of off-farm wages, institutional and cultural contraints, and physical and human capital. However, unlike previous studies land access was not found to significantly influnce the gender farm productivity gaps.

Table 5. Estimates of Farm Outputs (Beans and Millet)

\begin{tabular}{|c|c|c|c|c|c|c|c|c|c|c|c|c|}
\hline \multirow[b]{3}{*}{ logqtyharvested } & \multicolumn{8}{|c|}{ Beans } & \multicolumn{4}{|c|}{ Millet } \\
\hline & \multicolumn{2}{|c|}{ Aggregate } & \multicolumn{2}{|c|}{ Female Farmer } & \multicolumn{2}{|c|}{ Male Farmer } & \multicolumn{2}{|c|}{ Aggregate } & \multicolumn{2}{|c|}{$\begin{array}{l}\text { Female } \\
\text { Farmer }\end{array}$} & \multicolumn{2}{|c|}{ Male Farmer } \\
\hline & Coef. & $\mathrm{t}$ & Coef. & $\mathrm{t}$ & Coef. & $\mathrm{t}$ & Coef. & $\mathrm{t}$ & Coef. & $\mathrm{t}$ & Coef. & $\mathrm{t}$ \\
\hline \multicolumn{13}{|l|}{ Quantile 25} \\
\hline logavhrspentpd & 1.023 & $2.16^{* *}$ & 0.547 & 0.52 & 1.521 & $1.86^{*}$ & -0.519 & -0.66 & -0.611 & -0.78 & -1.195 & -1.03 \\
\hline logtotalemp & 0.129 & 0.62 & 0.073 & 0.18 & 0.198 & 0.44 & -0.330 & -1.17 & -0.531 & -1.28 & -0.304 & -0.85 \\
\hline machineava & -0.204 & -0.41 & -0.209 & -0.31 & -1.323 & -1.46 & -0.216 & -0.46 & -0.168 & -0.25 & -0.662 & -0.69 \\
\hline pesticisav & 0.293 & 1.31 & 0.025 & 0.03 & 1.090 & 1.6 & 1.377 & $1.98^{* *}$ & 1.543 & $1.68^{*}$ & 0.957 & 0.41 \\
\hline herbiciava & 0.413 & 1.4 & 0.623 & 1.33 & -0.313 & -0.46 & -0.354 & -0.55 & -0.433 & -0.62 & 0.192 & 0.08 \\
\hline fertiuse & 0.195 & 0.68 & 0.061 & 0.12 & 0.666 & 0.92 & -0.207 & -0.42 & -0.442 & -0.94 & 0.130 & 0.09 \\
\hline freeseed & 0.601 & 0.6 & 0.205 & 0.18 & - & - & 1.655 & $2.45^{* *}$ & 1.465 & $1.8^{*}$ & 2.309 & 1.2 \\
\hline animaltractnuse & 0.656 & $2.59^{* *}$ & 0.720 & 1.35 & 0.299 & 0.26 & 0.449 & 0.41 & 0.018 & 0.02 & 0.276 & 0.1 \\
\hline irrigatedplot & 0.170 & 0.18 & 0.440 & 0.4 & - & - & - & - & - & - & - & - \\
\hline landaccess & -0.412 & -1.2 & -0.120 & -0.16 & -0.464 & -0.75 & -0.297 & -0.49 & 0.060 & 0.16 & -1.289 & -0.89 \\
\hline locatn & 0.574 & 0.48 & 0.588 & 0.53 & 0.453 & 0.24 & -0.053 & -0.04 & -2.234 & -1.27 & -0.364 & -0.36 \\
\hline logage & -0.099 & -0.95 & -0.085 & -0.41 & -0.104 & -0.31 & 0.014 & 0.08 & 0.010 & 0.04 & -0.314 & -0.32 \\
\hline sex & -0.136 & -0.61 & - & - & - & - & 0.051 & 0.13 & & & & \\
\hline _cons & 3.161 & $2.69 * *$ & 3.915 & $1.88^{*}$ & 1.865 & 1.29 & 6.574 & $4.29 * * *$ & 7.153 & $5.25^{* * *}$ & 9.135 & $1.78^{*}$ \\
\hline $\begin{array}{l}\text { Pseudo } \mathrm{R}^{2} \\
\text { Quantile } 50\end{array}$ & & 0.14 & & 0.06 & & 0.24 & & 0.14 & & 0.27 & & 0.26 \\
\hline logavhrspentpd & 0.520 & 1.3 & -0.181 & -0.35 & 0.857 & $1.83^{*}$ & -0.411 & -1.01 & 0.214 & 0.28 & -0.617 & -0.56 \\
\hline logtotalemp & 0.119 & 1.08 & -0.195 & -1.17 & 0.119 & 0.35 & -0.134 & -0.59 & 0.698 & $1.96^{* *}$ & -0.114 & -0.39 \\
\hline machineava & -0.411 & -1.3 & -0.018 & -0.04 & -0.790 & -0.81 & -0.094 & -0.2 & -0.455 & -0.86 & -0.153 & -0.14 \\
\hline pesticisav & 0.212 & 0.75 & -0.574 & -0.86 & 0.454 & 0.77 & 0.560 & 1.17 & 0.538 & 0.8 & 0.599 & 0.34 \\
\hline
\end{tabular}




\begin{tabular}{|c|c|c|c|c|c|c|c|c|c|c|c|c|}
\hline herbiciava & 0.462 & $2.02^{* *}$ & 0.461 & 0.92 & -0.050 & -0.1 & -0.284 & -0.72 & 0.313 & 0.49 & -0.448 & -0.33 \\
\hline fertiuse & 0.060 & 0.29 & 0.040 & 0.11 & 0.111 & 0.23 & -0.124 & -0.35 & -0.100 & -0.23 & -0.276 & -0.2 \\
\hline freeseed & -0.504 & -0.72 & -0.455 & -0.75 & - & - & 0.549 & 0.96 & 0.378 & 0.68 & 1.071 & 0.78 \\
\hline animaltractnuse & 0.315 & 1.26 & 0.144 & 0.4 & 0.769 & 1.18 & 0.790 & 1.17 & 1.078 & 1.41 & 0.330 & 0.2 \\
\hline irrigatedplot & 0.783 & 1.31 & 0.614 & 1.3 & - & - & - & - & - & - & - & - \\
\hline landaccess & 0.032 & 0.15 & 0.504 & 1.7 & -0.432 & -0.88 & -0.347 & -0.85 & 0.131 & 0.37 & -0.587 & -0.57 \\
\hline locatn & -0.017 & -0.04 & -0.059 & -0.13 & -0.437 & -0.32 & 0.063 & 0.13 & -0.327 & -0.33 & -0.197 & -0.28 \\
\hline logage & 0.008 & 0.09 & 0.027 & 0.22 & 0.018 & 0.07 & -0.079 & -0.61 & 0.092 & 0.5 & -0.256 & -0.31 \\
\hline sex & -0.245 & -1.17 & - & - & - & - & -0.055 & -0.18 & & & & \\
\hline _cons & 4.328 & $4.98^{* * *}$ & 5.767 & $6.23 * * *$ & 3.736 & $3.48^{* *}$ & 7.333 & $8.83^{* * *}$ & 6.302 & $4.13 * * *$ & 8.371 & $1.71 *$ \\
\hline $\begin{array}{l}\text { Pseudo } \mathrm{R}^{2} \\
\text { Quantile } 75\end{array}$ & & 0.07 & & 0.08 & & 0.16 & & 0.11 & & 0.15 & & 0.23 \\
\hline logavhrspentpd & 0.308 & $1.65^{*}$ & -0.075 & -0.28 & 0.700 & $2.13^{* *}$ & -0.092 & -0.29 & 0.361 & 0.57 & -0.399 & -0.46 \\
\hline logtotalemp & 0.087 & 0.96 & -0.153 & -0.73 & 0.363 & 1.3 & -0.225 & -1.32 & 0.527 & $2.03 * *$ & 0.243 & -0.85 \\
\hline machineava & 0.495 & $2.53 * *$ & -0.516 & -1.21 & -0.916 & -1.22 & -0.417 & -1.42 & -0.180 & -0.34 & -0.761 & -0.79 \\
\hline pesticisav & 0.154 & 0.41 & -0.539 & -0.87 & 0.508 & 1.29 & 0.339 & 0.79 & 0.564 & 0.76 & 1.064 & 1.18 \\
\hline herbiciava & 0.514 & 1.28 & 0.581 & 1.48 & -0.064 & -0.21 & -0.125 & -0.48 & 0.102 & 0.18 & -1.205 & -0.91 \\
\hline fertiuse & 0.383 & $2.1^{* *}$ & 0.419 & 1.18 & 0.650 & $1.75^{*}$ & 0.163 & 0.67 & 0.057 & 0.21 & -0.328 & -0.34 \\
\hline freeseed & -0.284 & -1.3 & -0.698 & -0.99 & - & - & 0.680 & 1.32 & -0.304 & -0.69 & 1.271 & 1.56 \\
\hline animaltractnuse & 0.160 & 0.68 & -0.150 & -0.57 & 0.023 & 0.04 & 0.364 & 0.82 & 0.442 & 1.04 & 0.748 & 0.7 \\
\hline irrigatedplot & 0.067 & 0.18 & 0.040 & 0.07 & - & - & - & - & - & - & - & - \\
\hline landaccess & 0.510 & $2.57^{* *}$ & 0.493 & $1.86^{*}$ & 0.467 & 1.08 & -0.184 & -0.6 & 0.126 & 0.22 & -1.100 & -1.72 \\
\hline locatn & 0.239 & 0.71 & -0.220 & -0.64 & 0.555 & 0.91 & -0.044 & -0.15 & 0.342 & 0.37 & -0.645 & -1.34 \\
\hline logage & 0.138 & $1.95^{*}$ & 0.075 & 0.67 & 0.097 & 0.46 & -0.051 & -0.38 & 0.012 & 0.08 & -0.628 & -1.07 \\
\hline sex & -0.292 & $-1.96^{*}$ & - & - & - & - & 0.034 & 0.15 & - & - & - & - \\
\hline _cons & 4.638 & $12.59 * * *$ & 5.839 & $8.6^{* * *}$ & 3.380 & $4.92 * * *$ & 7.196 & $8.9^{* * *}$ & 6.454 & $4.97 * * *$ & 10.202 & $2.83^{* *}$ \\
\hline Pseudo R ${ }^{2}$ & & 0.13 & & 0.15 & & 0.21 & & 0.10 & & 0.16 & & 0.28 \\
\hline Obs & & 167 & & 87 & & 80 & & 96 & & 59 & & 37 \\
\hline
\end{tabular}

Source: Computed using STATA

Note: $* * *, * * *$ implies significant at $10 \%, 5 \%$, and $1 \%$ respectively. - implies variables dropped due to collinearity problem

\section{Conclusion}

This study has further drawn interest in agricultural gender gaps, it sources and consequences in Nigeria using the Living Standards Measurement Study-Integrated Surveys on Agriculture (LSMS-ISA) for Nigeria in the wave 2 panel studies for the year 2012/2013. On the whole, gender productivity gaps in agriculture in Nigeria is mild implying that both male and female face similar input constraints resulting in low farm productivity. However, the gender productivity gaps is more pronounced in certain crops than other given the variation 
in responsiveness of farm outputs to inputs used and other variables. Specifically, gender productivity gaps are more pronounced in cassava, yam and maize production while it is rather mild in other three sampled crops. The productivity gaps are particularly traceable to farming experience in favour of men and labour market imperfection which is biased against women. That is, while men, on the average, have longer farming experience than women, women pay higher wages than men which is traceable to labour market discriminations, in terms of longer off-farm time spent by women plot managers, and rooted in institutional and cultural contraints.

In terms of policy, Nigeria could do better in production of some of the agricultural commodities it already has a leading position such as yam and maize if gender productivity gaps is addressed. Specifically, labour market imperfections against women need to be addressed given that agricultural sector employs most women in rural Nigeria. One way of going about this is to have an efficient collective bargaining to address payable gender wage gap. That is, wages and other conditions of farm employment should be negotiated by an organized body of farmers. Correcting labour market failures in this regards will have a positive impact female-managed farm outputs. However, this requires a formalized farming system which is presently lacking in Nigeria.

\section{References}

1. Adenugba, A., Raji-Mustapha, N. (2013): The Role of Women in Promoting Agricultural Productivity and Developing Skills for Improved Quality of Life in Rural Areas, Journal of Engineering, Vol. 3, No. 8, pp. 51-58.

2. African Development Bank (2015): Economic Empowerment of African Women through Equitable Participation in Agricultural Value Chains. Abidjan: African Development Bank, (Available at: https://www.afdb.org/fileadmin/uploads/afdb/ Documents/Publications/Economic Empowerment of African Women through Equitable Participation in Agricultural Value Chains.pdf).

3. Afolabi, M. (2008): Women as Pillars of National Economy in Nigeria: A Study of Economic Activities of Rural Women in Six Local Government Areas of Ondo State. Torino, Italy: IAFFE Summer Conference, International Association for Feminist.

4. African Economic Outlook. (2012): Promoting Youth Employment, OECD, AfDB, UNDP, UNECA.

5. Aguilar, A., Carranza, A., Goldstein, M., Kilic, T., Oseni, G. (2014): Decompostion of Gender Differentials in Agricultural Productivity in Ethiopia, Policy Research Paper 6764, World Bank.

6. Ajewole, O., Eyitayo, O., Ojehomon, V., Agboho-Noameshie, R., Diagne, A. (2015): Gender Analysis of Agricultural Innovation and Decision Making among Rice Farming Household in Nigeria, Journal of Agricultural Informatics, vol. 6, no. 2, pp. 72-82.

7. Ali, D., Bowen, D., Deininger, K., Duponchel, M. (2015): Investigating the gender gap in agricultural productivity: Evidence from Uganda, Policy Research Working 
Paper, No.7262, The World Bank.

8. Ayoola, J., Kudi, T., Dangbegnon, C., Dauda, C., Mando, A., Amapu, I., Ezui, K. (2012): Gender Perspectives of Action Research for Improved Rice Value Chain in Northern Guinea Savanna, Nigeria, Journal of Agricultural Sciences, vol. 4, no. 1, pp. 211-218.

9. Budget Office of the Federation (2016): Appropriation Bill. Abuja: Budget Office of the Federation.

10. Cnetral Bank of Nigeria (2015): Statistical Bulletine. Cnetral Bank of Nigeria.

11. Daymont, T. N., Andrisani, P., J. (1984): Job preferences, college major, and the gender gap in earnings, Journal of Human Resources, Vol. 19, pp. 408-428.

12. Dejene, Y. (2007): Promoting Women's Economic Empowerment in Africa. African Development Bank, (Available at: https://www.afdb.org/fileadmin/uploads/afdb/ Documents/Knowledge/25040341-FR-DRAFT-DEJENE.9-15-07DOC.PDF ).

13. Doss, C., Morris, M. (2001): How Does Gender Affect the Adoption of Agricultural Innovations? The Case of Improved Maiza Technology in Ghana, Agricultural Economics, Vol. 25, No. 1, pp. 27-39.

14. Enete, A., Nweke, F., Tollens, E. (2004). Gender and Cassava Processing in Africa, Quaterly Journal of International Agriculture, Vol. 43, No. 1, pp. 57-69.

15. Food and Agriculture Organization (2006): The State of Food and Agriculture. Rome: Food and Agriculture Organization of the United Nations.

16. Food and Agriculture Organization (2011): The State of Food and Agriculture. Rome: Food and Agriculture Organization .

17. Federal Ministry of Agriculture and Rural Development (2016): The Agriculture Promotion Policy (2016-2020): Building on the Successes of the ATA, Closing Key Gaps. Abuja: Federal Ministry of Agriculture and Rural Development.

18. Fortin, N. (2006): Greed, Altruism, and the Gender Wage Gap, Working Paper, Department of Economics: University of British Columbia, (Avaialable at: http:// faculty.arts.ubc.ca/nfortin/Fortinat8.pdf)

19. Fortin, N., Lemieux, T., Firpo, S. (2011): Decomposition Methods In O. Ashenfelter, \& D. Card (Eds.), Handbook of Labour Economics (pp. 1-102). Amsterdam, Netherlands: North-Holland.

20. Hertz, T., Winters, P., A.P, D., Quinones, E., Azzari, B., Davis, B., Zezza, A. (2009): Wage Inequality in International Perspective: Effects of Location, Sector and Gender. Rome: FAO.

21. IFAD. (2003): Mainstreaming a Gender Perspective in IFAD's Operations: Plan of Action 2003-2006, Rome: International Fund for Agricultural Development .

22. Jann, B. (2008): The Blinder-Oaxaca decomposition for linear regression models, The Stata Journal, Vol. 8, No. 4, pp. 453-479

23. Kilic, T., Palacios-Lopez, A., Goldstein, M. (2013): Caught in a Productivity Trap: A 
Distributional Perspective on Gender Differences in Malawian Agriculture. Policy Research Working Paper, 6381, The World Bank.

24. Lopez, R., Romano, C. (2000): Rural Poverty in Hondras: Asset Distribution and Liquidity Constraints. In R. Lopez, \& A. Valdes (Eds.), Rural Poverty in Latin America: Analytics, New Empirical Evidence and Policies. MacMillan Press (UK) and Saint Martin's Press (USA).

25. Manfre, C., Rubin, D., Allen, A., Summerfield, G., Colverson, K., Akeredolu, M. (2013): Reducing the Gender Gap in Agricultural Extension and Advisory Services: How to Find the Best Fit for Men and Women Farmers. MEAS Discussion Paper 2.

26. March, C., Smyth, I., Mukhopadhyay, M. (1999): A Guide to Gender-Analysis Frameworks. Oxfam GB Publications.

27. Moock, P. (1976): The Efficiency of Women as Farm Managers: Kenya, American Journal of Agricultural Economics, Vol. 58, No. 5, pp. 831-835.

28. Mukasa, A. N., Salami, A. O. (2015): Gender productivity differentials among smallholder farmers in Africa: A cross-country comparison, AfDB Working Paper No.231

29. National Bureau of Statistics. (2015): Nigerian Gross Domestic Product, Quarter Four 2015 GDP Report. National Bureau of Statistics.

30. Ogunlela, Y., Mukhtar, A. (2009): Gender Issues in Agriculture and Rural Development in Nigeria: The Role of Women, Humanity \& Social Sciences Journal, Vol. 4, No. 1, pp. 19-30.

31. Oladeebo, J., Fajuyigbe, A., A. (2007): Technical Effciency of Men and Women Upland Rice Farmers in Osun State, Nigeria, Journal of Human Ecology, Vol. 22, No. 2, pp. 93-100.

32. Olakojo, S., A. (2016): Seasonal Labour Market Rigidities: Impact on Farm Employment and Wages in Nigeria, Economics of Agriculture, Vol. 63, No.4, pp. 1123-1140

33. O’Neill, J., O’Neil, D. (2006): What do Wage Differentials tell about Labour Market Discriminations? In S. Polachek, C. Chiswick, and H. Rapoport (Eds.), The Economics of Immigration and Social Diversity (Reseearch in Labor Economics Series, Vol. 24) (pp. 293-357). Ansterdam: Elsevier.

34. Oseni, G., Corral, P., Goldstein, M., Winters, P. (2013): Explaining Gender Differnetials in Agricultural Production in Nigeria. Washington, DC: World Bank.

35. Palacios-Lopez, A., Lopez, R. (2014): Gender Differences in Agricultural Productivity: The Role of Market Imperfections. Department of Agricultural and Resources Economics WP 14-01, (Available at http://ageconsearch.umn.edu/ bitstream/164061/2/14-01.pdf )

36. Peterman,A., Behrman, J., Quisumbing, A. (2011b): AReview of Empirical Evidence on Gender Differences in Nonland Agricultural Inputs, Technology and Services in Developing Countries, International Food Policy Research Institute, Discussion 
Paper 00975.

37. Peterman, A., Quisumbing, A., Behrman, J., Nkonya, E. (2011a): Understanding the Complexities Surrounding Gender Differences in Agricultural Productivity in Nigeria and Uganda. Journal of Development Studies, vol. 47, pp. 1482-1509.

38. Quisumbing, A. (1995): Gender Differences in Agrciultural Productivity: A Survey of Empirical Evidence, International Food Policy Research Institute: Food Consumption and Nutrition Division.

39. Quisumbing, A., Behrman, J. (2010): Understanding the Complexities Surounding Gender Differences in Agricultural Productivity in Nigeria and Uganda, International Food Policy Research Institute (IFPRI) Discussion Paper.

40. Timothy, A., Adeoti, A., I. (2006): Gender Inequalities and Economic Efficiency: New Evidence from Cassava based Farm Holdings in Rural South-Western Nigeria, $\quad$ African Developmenmt Review, vol. 18, no. 3 pp. 428-443.

41. Udry, C. (1996): Gender, Agricultural Production, and the Theory of the Household, Journal of Political Economy, vol. 104, no.5, pp. 1010-1046.

42. UNECA. (1982): Women: The Neglected Human Resource for African Development. Canadian Journal of African Studies, vol. 6, no. 2, pp. 359-370, (Avialable at: http:// www.jstor.org/stable/pdf/484209.pdf?refreqid=excelsior\%3Ac8cda1ce494d90b9e8 $\underline{92110 \mathrm{a} 675927 \mathrm{c} 5}$ )

43. World Bank (2007): Global Monitoring Report 2007: Millennium Development Goals - Confronting Challenges of Gender Equity and Fragile States. Washington, D.C.: World Bank.

44. World Bank, FAO, IFAD. (2009): Gender and Agriculature. World Bank and United Nations.

\section{Appendix}

Table A1. List of Farm Equipment and Machinery

\begin{tabular}{|l|r|r|}
\hline Farm equipment/machine & Frequency & Percent \\
\hline Canoe & 14 & 0.1 \\
\hline Cutlass & 4083 & 35.8 \\
\hline Fishing net & 23 & 0.2 \\
\hline Harvester & 6 & 0.1 \\
\hline Hoe & 5166 & 45.3 \\
\hline Outboard & 3 & 0.0 \\
\hline Pickup & 6 & 0.1 \\
\hline Planter & 6 & 0.1 \\
\hline Plough & 56 & 0.5 \\
\hline
\end{tabular}




\begin{tabular}{|l|r|r|}
\hline Ridger & 55 & 0.5 \\
\hline Sickle & 620 & 5.4 \\
\hline Sprayer & 295 & 2.6 \\
\hline Sprinkle & 8 & 0.1 \\
\hline Tractor & 4 & 0.0 \\
\hline Water Pump & 23 & 0.2 \\
\hline Wheel barrow & 410 & 3.6 \\
\hline Others & 637 & 5.7 \\
\hline Total & 11409 & 100 \\
\hline
\end{tabular}

Source: Computed using STATA

Table A2. Major Crops Grown among Nigerian Farmers

\begin{tabular}{|l|r|r|r|}
\hline cropID & \multicolumn{1}{l|}{ Freq. } & Percent & \multicolumn{1}{l|}{ Cum. } \\
\hline Cassava & 2,048 & 19.83 & 19.83 \\
\hline Maize & 1,971 & 19.08 & 38.91 \\
\hline Yam & 952 & 9.22 & 48.13 \\
\hline Guinea Corn & 1,486 & 14.39 & 62.51 \\
\hline Beans & 1,065 & 10.31 & 72.82 \\
\hline Millet & 886 & 8.58 & 81.4 \\
\hline Groundnut & 501 & 4.85 & 86.25 \\
\hline Rice & 341 & 3.3 & 89.55 \\
\hline Okro & 313 & 3.03 & 92.58 \\
\hline Pumpkin & 131 & 1.27 & 93.85 \\
\hline Cocoa & 495 & 4.79 & 98.64 \\
\hline Palm Tree & 136 & 1.32 & 99.96 \\
\hline & & & \\
\hline Total & 10,329 & 100 & \\
\hline
\end{tabular}

Sources: Computed using STATA 